ISSN: $1858-4837$

E-ISSN: 2598-019X

Volume 13, Nomor 1 (2018),

https://jurnal.uns.ac.id/region

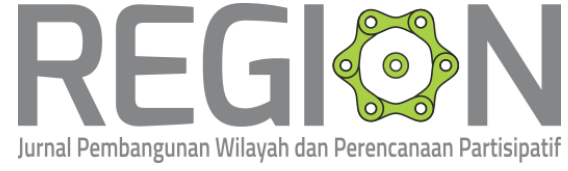

\title{
Kesiapan Aksesibilitas Stasiun Solo Balapan dalam Melayani Trayek Kereta Api Penghubung Bandara Adi Soemarmo dan Kota Surakarta
}

\author{
Readiness of Solo Balapan Train Stations' Accessibility in Serving \\ Airport Rail Linking Adi Soemarmo Airport and Surakarta City
}

\author{
Ghavi Yuda Sefaji ${ }^{a *}$, Soedwiwahjono ${ }^{b}$, Kuswanto Nurhadi ${ }^{c}$ \\ a Prodi Perencanaan Wilayah dan Kota, Fakultas Teknik, Universitas Sebelas Maret \\ ${ }^{b}$ Prodi Perencanaan Wilayah dan Kota, Fakultas Teknik, Universitas Sebelas Maret \\ ${ }^{c}$ Prodi Teknik Sipil, Fakultas Teknik, Universitas Sebelas Maret \\ *email: gys1995@yahoo.com
}

\begin{abstract}
Abstrak
Pembangunan Trayek Kereta Api Akses Bandara Adi Soemarmo dan Kota Surakarta adalah salah satu program Kementerian Perhubungan RI untuk memberikan suatu moda transportasi umum menuju ke Bandara Lokal, yaitu Bandara Adi Soemarmo yang didasarkan pada RIPNAS 2030 Kementerian Perhubungan RI, RTRW Kota Surakarta 2011 - 2031 serta RTRW Kabupaten Boyolali 2011 - 2031. Salah satu Prasarana Kereta Api yang akan melayani trayek Kereta Api Bandara ini adalah Stasiun Solo Balapan Kota Surakarta. Penelitian ini membahas kesiapan aksesibilitas Stasiun Solo Balapan yang akan melayani trayek Kereta Bandara. Penelitian ini menggunakan data primer berupa observasi lapangan serta data sekunder. Teknik analisis yang digunakan adalah metode analisis skoring. Aksesibilitas dari Stasiun Solo Balapan menuju kawasan pusat kota Surakarta kurang baik karena harus menggunakan satu jenis moda transportasi umum untuk mengaksesnya dari kawasan pusat kota. Aksesibilitas pengunjung dari Stasiun Solo Balapan menuju ke tempat lain kurang baik karena stasiun tidak terintegrasi dengan jaringan pedestrian kota Surakarta. Berdasarkan hal -hal tersebut, kesiapan aksesibilitas Stasiun Solo Balapan dalam melayani Trayek Kereta Api Akses Bandara termasuk dalam kategori siap bersyarat.
\end{abstract}

Keywords: Kesiapan; Stasiun Solo Balapan; Aksesibilitas; Trayek; Kereta Akses Bandara; Kesiapan Trayek Kereta Api Akses Bandara.

\begin{abstract}
Construction and development of Adi Soemarmo Airport railway link and Surakarta city is one of many programs from Ministry of Transportation Republic of Indonesia to give a mode of transportation to a local Airport, which is Adi Soemarmo Airport based on Ministry of Transportation's RIPNAS 2030, Surakarta City's RTRW 2011 - 2031 and Boyolali Regency's RTRW 2011 - 2031. One if the rail infrastructure that will serve the Airport rail link is Solo Balapan Train Station. This research aims to explain and analyze the readiness of Solo Balapan Train Stations' accessibility in serving the Airport Rail link. This research uses primary datas, namely field observation and secondary datas. Analysis method used in this research are scoring analysis method. Accessibility from Solo Balapan Train Station to the Surakarta City center was not good because to access the Train Station from the City center area, people had to use at least one mode of public transport. Accessibility of Train Station passengers and visitors from the train station to other places were also not good because the train station wasn't integrated with Surakarta City's pedestrian network. Based on those existing conditions, the readiness of
\end{abstract}


Solo Balapan Train Stations' accessibility in serving Adi Soemarmo Airport Rail Link are categorized as Ready with some requirements.

Keywords: Readiness; Solo Balapan Train Station; Accessibility; Rail Link; Airport Rail; Readiness of Airport Rail Link

\section{PENDAHULUAN}

Kota Surakarta dan kawasan perkotaan Surakarta kini telah berkembang sangat pesat dan jumlah arus lalu lintas yang terjadi sehari - hari jumlahnya sangat banyak. Berbagai jenis moda transportasi umum telah dibangun untuk melayani pergerakan penduduk dari dalam maupun luar kawasan perkotaan Surakarta untuk melakukan pergerakan. Moda transportasi umum yang tersedia antara lain adalah moda transportasi udara, yaitu Bandar Udara Adi Soemarmo di daerah Ngemplak, Boyolali yang melayani masyarakat kawasan perkotaan Surakarta, serta moda transportasi darat yang terbagi dalam dua jalur gerak, yaitu moda transportasi darat jalur rel dan jalur jalan.

Berdasarkan data statistika penerbangan dari Badan Pusat Statistika Provinsi Jawa Tengah bulan Juli dan September 2016, jumlah keberangkatan penumpang angkutan udara di Bandara Adi Soemarmo, baik untuk penerbangan domestik maupun internasional per Januari 2017 lalu mencapai 100.533 penumpang, sedangkan jumlah kedatangannya mencapai angka 100.657 penumpang. Jumlah yang besar ini disebabkan karena terjadinya arus mudik dan balik lebaran, dimana masyarakat memilih untuk menggunakan moda transportasi udara untuk bepergian dengan lebih cepat. Dibandingkan dengan statistik penerbangan di bulan Mei 2016 sebelumnya, dimana jumlah keberangkatan domestik maupun internasional sebanyak 87.379 penumpang dan jumlah kedatangan sebanyak 88.822 penumpang, maka terdapat peningkatan jumlah penumpang yang cukup signifikan, menandakan bahwa lebih banyak masyarakat yang mulai menggunakan moda transportasi udara.

Salah satu rencana pembangunan untuk menangani masalah ini yang sudah dicanangkan dalam peraturan pemerintah adalah pembangunan rel kereta api menuju Bandara langsung dari stasiun di Kota Surakarta. Hal tersebut tercantum dalam RTRW Kota Surakarta tahun 2011 - 2031, RTRW Kabupaten Boyolali Tahun 2011 - 2031, serta Rencana Induk Perkeretaapian Nasional tahun 2030. Kemudian rencana pembangunan rel kereta api tersebut akan dilaksanakan pada awal tahun 2017, dan dijadwalkan beroperasi pada tahun 2019 mendatang. (kereta-api.info: Proyek Stasiun Kereta Api Bandara Adi Soemarmo Solo Mulai Digarap Tahun 2017, 15 Oktober 2016). 
Kereta api bandara didefinisikan sebagai layanan kereta api yang memberikan trayek dan stasiun dalam jarak berjalan kaki dari terminal bandara, atau tempat dimana kendaraan airport shuttle penghubung terminal bandara dan stasiun kereta berada (Schank, 1999). Diasumsikan jika jarak stasiun dan trayek kereta api beserta terminal bandara cukup dekat untuk ditempuh dengan berjalan atau menggunakan kendaraan airport shuttle, maka trayek tersebut dianggap unggul dibandingkan transportasi jalan biasa. Beberapa aspek yang penting berada pada prasarana kereta api, khususnya stasiun kereta api bandara. Sebelumnya telah disebutkan oleh Schank (1999) dan Kouwenhoven (2008) bahwa stasiun kereta api bandara di kawasan bandara haruslah menyatu atau berdekatan dengan Terminal Bandara, atau untuk stasiun di kawasan kota sebaiknya memiliki aksesibilitas baik dengan kawasan pusat kota dan terintegrasi langsung dengan trayek kereta api lainnya yang melewati stasiun tersebut dan terintegrasi dengan moda transportasi umum lainnya.

Salah satu prasarana transportasi yang akan melayani trayek Kereta api Bandara ini adalah stasiun Solo Balapan, yang termasuk dalam salah satu stasiun besar yang melayani wilayah Kota Surakarta dan sekitarnya di samping stasiun Solo Purwosari dan Solo Jebres. Stasiun Solo Balapan menjadi simpul trayek trayek kereta api antarkota dari bagian Utara dan Selatan Pulau Jawa, dan dengan adanya tambahan trayek Kereta api Bandara ini, maka jumlah penumpang yang melakukan pergerakan menuju Stasiun Solo Balapan diprediksi juga akan naik di masa mendatang. Maka dari itu pada penelitian ini, penulis ingin mengetahui tingkat kesiapan aksesibilitas Stasiun Solo Balapan dalam melayani trayek kereta api penghubung Bandara Adi Soemarmo ke Kota Surakarta.

\section{KAJIAN LITERATUR}

\subsection{Kesiapan}

Berdasarkan Kamus Besar Bahasa Indonesia (KBBI), kesiapan memiliki kata dasar "siap" yang berarti "Sudah sedia". Kemudian dalam pemahamannya, kesiapan adalah kondisi di mana orang, sistem, atau organisasi siap dalam menghadapi sebuah situasi dan melaksanakan serangkaian tindakan yang terencana. Kesiapan terjadi jika ada ketuntasan dalam rencana, ada kecukupan dan latihan dari pelaku, serta ketersediaan dukungan pelayanan atau sistem (www.businessdictionary.com).

a. Ketuntasan dalam perencanaan; merupakan terselesaikannya rencana rencana yang telah dibuat secara menyeluruh 
Ghavi Yuda Sefaji dkk, Kesiapan Aksesibilitas Stasiun...

b. Kecukupan dan pelatihan dari pelaku; kecukupan berarti dapat memenuhi kebutuhan tanpa perlu ditambah lagi

c. Ketersediaan dukungan pelayanan atau sistem; ketersediaan berarti adanya suatu sarana yang dapat mendukung pelayanan atau sistem untuk dapat dioperasikan dalam waktu yang ditentukan

\subsection{Aksesibilitas}

Aksesibilitas adalah suatu ukuran kenyamanan atau kemudahan mengenai cara lokasi tata guna lahan berinteraksi satu sama lain dan mudah atau sulitnya lokasi tersebut dicapai melalui sistem jariingan transportasi (Black, 1981 dalam Miro, 2005). Aksesibilitas adalah konsep yang menggabungkan sistem pengaturan tata guna lahan secara geografis dengan sistem jaringan transportasi yang menghubungkannya. Menurut Duncan dan Hollander (1977), aksesibilitas berupa fasilitas transportasi umum dan kedekatan dengan konsumen yang potensial (dekat dengan daerah perumahan, perkantoran, dan perdagangan jasa).

Tingkat aksesibilitas dapat diukur dengan ketersediaan transportasi umum dan dengan jarak pencapaian yang singkat. Selain faktor jrak, tingkat kemudahan pencapaian tujuan juga dapat dipengaruhi oleh faktor - faktor lain, seperti faktor waktu tempuh, faktor biaya/ongkos perjalanan, faktor intensitas guna lahan, dan faktor pendapatan orang yang melakukan perjalanan.

\subsection{Kereta Api Bandara}

Menurut UU Republik Indonesia no. 23 tahun 2007 tentang Perkeretaapian dan PP Republik Indonesia no. 68 tahun 1998 tentang Prasarana dan Sarana Kereta Api, apa yang dimaksud dengan kereta api merupakan suatu kendaraan dengan tenaga gerak, yang berjalan sendiri maupun dirangkaikan dengan kendaraan lainnya, yang akan maupun sedang bergerak di atas rel. Sistem perkeretaapan membutuhkan sarana dan prasarana khusus untuk pengoperasiannya. Prasarana kereta api terdiri dari jalur kereta api (rel, temasuk wessel), stasiun kereta api beserta fasilitas sesuai dengan tingkatan kelasnya, serta fasilitas operasi kereta api, seperti sistem persinyalan dan fasilitas perawatan sarana KA (Dipo). Sedangkan sarana kereta api terdiri dari lokomotif, kereta, gerbong, dan peralatan khusus lainnya.

Penyelenggaraan sistem transportasi rel untuk akses menuju bandara berawal dari pembangunan bandara yang berada jauh di luar kota karena pertimbangan keselamatan operasional penerbangan. Hal tersebut menyebabkan waktu tempuh pelayanan penumpang pesawat justru lebih lama di darat daripada 
Region, Vol. 13, No.1, Januari 2018: 50-63

perjalanan udara itu sendiri. Oleh sebab itu, diperlukan moda transportasi yang menghubungkan pusat kota dengan bandara yang cepat, aman, nyaman, dan memberikan berbagai kemudahan aksesibilitas, yakni KA Bandara (Airport rail link). Airport rail link adalah kereta penumpang yang menghubungkan antara bandara dengan pusat kota yang dilayani oleh bandara tersebut. Biasanya stasiun KA Bandara juga menyediakan layanan perhubungan dengan kota lainnya dalam suatu wilayah yang masih menjadi jangkauan pelayanan bandara tersebut. Maksud dan tujuan pembangunan jalur KA Bandara antara lain adalah untuk mengurangi beban area parkir di kawasan bandara, mendorong penggunaan sarana transportasi umum, meningkatkan aksesibilitas dari bandara ke pusat kota maupun sebailiknya, dan sebagai penarik bagi wisatawan yang berkunjung.

Teknis perencanaan ini akan disesuaikan dengan teori keberhasilan trayek Kereta Bandara dari Kouwenhoven (2008), JICA (2009), Eichinger \& Knorr (2004), Peterson (2012), Airport Cooperative Research Program (ACRP) (2008), Schank (1999), dan Jou et al (2011), yang menyatakan bahwa keberhasilan trayek Kereta Bandara tergantung dari (a) Tujuan Pergerakan calon penumpang pesawat; (b) Lokasi Stasiun Bandara yang Aksesibel; (c) Akses langsung ke pusat kota; (d) Akses Menuju Tempat Lain via berjalan kaki / moda transportasi lainnya; (e) Biaya yang harus dikeluarkan penumpang; (f) Tingkat Keandalan Pelayanan; (g) Kecepatan dan waktu perjalanan kereta; (h) Kenyamanan perjalanan; (i) Frekuensi Operasi Moda; dan (j) Keamanan Perjalanan. Dari teori tersebut, JICA, Kouwenhoven, dan ACRP menyebutkan akses langsung menuju pusat kota adalah faktor penting dalam keberhasilan moda KA Bandara karena pengunjung dan pekerja membutuhkan akses menuju pusat kota untuk menuju pusat aktivitas kota untuk beraktivitas atau berganti moda. Trayek KA Bandara yang terhubung dengan pusat kota akan banyak menjadi pilihan moda bagi penumpang datang atau berangkat.

Kemudian akses dari stasiun pelayan trayek KA Bandara menuju tempat lain dengan berjalan kaki ataupun menggunakan moda transportasi lainnya penting dalam keberhasilan moda KA Bandara. Aksesibilitas stasiun pelayan Trayek KA Bandara yang tinggi dapat mempermudah pengunjung dan pekerja bandara untuk menggunakan KA Bandara

\section{METODE PENELITIAN}

Pendekatan penelitian yang akan digunakan dalam penelitian mengenai kesiapan stasiun Solo Balapan dalam melayani trayek kereta api penghubung Bandara Adi Soemarmo dan Kota Surakarta ini bersifat deduktif. Jenis penelitian 
Ghavi Yuda Sefaji dkk, Kesiapan Aksesibilitas Stasiun... yang akan dilakukan dalam penelitian mengenai kesiapan aksesibilitas stasiun Solo Balapan dalam melayani trayek kereta api penghubung Bandara Adi Soemarmo dan Kota Surakarta ini adalah jenis penelitian kuantitatif. Pada prosesnya menggunakan perhitungan statistik yang di dalamnya terdapat angka-angka. Variabel pada penelitian ini sebagai berikut:

Tabel 1. Definisi Variabel Penelitian

\begin{tabular}{|c|c|c|c|}
\hline Variabel Penelitian & $\begin{array}{c}\text { Keterangan } \\
\text { Variabel }\end{array}$ & Penjelasan & Justifikasi \\
\hline \multirow{5}{*}{$\begin{array}{l}\text { Aksesibilitas trayek } \\
\text { menuju kawasan } \\
\text { pusat kota }\end{array}$} & $\begin{array}{l}\text { Definisi } \\
\text { Operasional }\end{array}$ & $\begin{array}{l}\text { Ukuran kemudahan mencapai } \\
\text { pusat kota menggunakan moda } \\
\text { kereta api bandara }\end{array}$ & \multirow{5}{*}{$\begin{array}{l}\text { Coogan } \\
(2008)\end{array}$} \\
\hline & Parameter & $\begin{array}{l}\text { Aksesibilitas yang tinggi dari } \\
\text { stasiun trayek ke pusat kota }\end{array}$ & \\
\hline & \multirow{3}{*}{ Indikator } & $\begin{array}{l}\text { Jika jarak stasiun trayek ke } \\
\text { pusat kota dapat ditempuh } \\
\text { dengan berjalan kaki }\end{array}$ & \\
\hline & & $2 \begin{array}{l}\text { Jika jarak stasiun trayek ke } \\
\text { pusat kota dapat ditempuh } \\
\text { dengan satu jenis moda } \\
\text { transportasi umum }\end{array}$ & \\
\hline & & $\begin{array}{l}\text { Jika jarak stasiun trayek ke } \\
\text { pusat kota dapat ditempuh } \\
\text { dengan lebih dari satu jenis } \\
\text { moda transportasi umum. }\end{array}$ & \\
\hline \multirow{4}{*}{$\begin{array}{l}\text { Alssesibilitas stasiun } \\
\text { bandara dan stasiun } \\
\text { kota menuju tempat } \\
\text { lain via berjalan } \\
\text { kaki/moda } \\
\text { transportasi lainnya } \\
\text { dan sebaliknya }\end{array}$} & $\begin{array}{l}\text { Definisi } \\
\text { Operasional }\end{array}$ & $\begin{array}{l}\text { Ukuran kemudahan mencapai } \\
\text { suatu lokasi dengan berjalan } \\
\text { kaki atau dengan transportasi } \\
\text { umum }\end{array}$ & \multirow{4}{*}{$\begin{array}{l}\text { Eichinger } \\
\text { dan Knorr } \\
(2004), \\
\text { Coogan } \\
(2008), \\
\text { JICA (2009) }\end{array}$} \\
\hline & Parameter & $\begin{array}{l}\text { Ketersediaan lahan parkir yang } \\
\text { memadai, moda transportasi } \\
\text { umum dan jaringan pedestrian } \\
\text { yang terintegrasi pada stasiun } \\
\text { trayek }\end{array}$ & \\
\hline & \multirow[b]{2}{*}{ Indikator } & $\begin{array}{l}\text { Stasiun trayek memiliki } \\
\text { semua karakteristik berikut: } \\
\text { telah menyediakan lahan } \\
\text { parkir yang memadai, } \\
\text { terhubung dengan jalur } \\
\text { pedestrian, dan konektivitas } \\
\text { dengan trayek moda } \\
\text { pengumpan yang lengkap }\end{array}$ & \\
\hline & & $\begin{array}{l}\text { Stasiun trayek memiliki dua } \\
\text { (2) dari karakteristik berikut: } \\
\text { menyediakan lahan parkir } \\
2 \text { yang memadai, terhubung } \\
\text { dengan jalur pedestrian, dan } \\
\text { konektivitas dengan trayek } \\
\text { moda pengumpan yang } \\
\text { lengkap }\end{array}$ & \\
\hline
\end{tabular}


Region, Vol. 13, No.1, Januari 2018: 50-63

\begin{tabular}{|c|c|c|c|}
\hline Variabel Penelitian & $\begin{array}{c}\text { Keterangan } \\
\text { Variabel }\end{array}$ & Penjelasan & Justifikasi \\
\hline & 1 & $\begin{array}{l}\text { Stasiun trayek hanya } \\
\text { memiliki satu (1) atau sama } \\
\text { sekali tidak memiliki } \\
\text { karakteristik berikut: } \\
\text { menyediakan lahan parkir } \\
\text { yang memadai, terhubung } \\
\text { dengan jalur pedestrian, dan } \\
\text { trayek moda pengumpan }\end{array}$ & \\
\hline
\end{tabular}

Sumber: Peneliti, 2017

Variabel-variabel diatas akan diukur dengan menggunakan teknik pengumpulan data sekunder, dan data primer (observasi lapangan, kuesioner). Sementara itu, teknik analisis yang digunakan adalah teknik analisis skoring. Teknik analisis skoring dalam penelitian ini menggunakan metode Skala Likert. Skala Likert merupakan metode penskalaan dengan menempatkan serangkaian stimulus dalam suatu kontinum poin. Metode penskalaan berpusat pada respons subjek dibuat dalam suatu rentang poin tertentu, metode disusun berdasarkan distribusi respons subjek (Setiawati, dkk., 2013). Jadi, Skala Likert merupakan metode skoring yang cara menghimpun respons subjek terhadap suatu fenomena/persoalan dengan pertanyaan/pernyataan yang didalamnya terdapat serangkaian pilihan/poin. Dalam penelitian ini teknik analisis data skoring dilakukan dalam analisis variabel kesiapan aksesibilitas Stasiun Solo Balapan dalam melayani Kereta Api penghubung Bandara Adi Soemarmo dengan Kota Surakarta. Skor yang diberikan pada masing-masing hasil analisis variabel berdasarkan indikatornya yaitu 3 bila sangat siap, 2 bila siap bersyarat, dan 1 bila tidak siap. Masing-masing skor indikator tersebut kemudian dibagi berdasarkan variabel, sub variabel dan indikatornya.

Nilai maksimal dari hasil skoring adalah 6 yang didapatkan dari hasil perkalian nilai skor tertinggi (3) dengan jumlah variabel (2), sedangkan nilai minimal dari hasil skoring sebelumnya adalah 2 , yang didapatkan dari hasil perkalian skor terendah (1) dengan jumlah variabel (2). Setelah didapatkan nilai maksimal dan nilai minimal maka dilanjutkan dengan mencari interval.

Interval

$$
\begin{aligned}
& =\frac{\text { Nilai Max-Nilai Min }}{\text { Jumlah Kelas }} \\
& =\frac{6-2}{3}=1,33
\end{aligned}
$$

Setelah didapatkan nilai interval, maka dapat diketahui kategori hasil skoring sebagai berikut:

Sangat Siap : $4,67-6$

Siap Bersyarat : 3,34-4,66

Tidak Siap $\quad: 2-3,33$ 
Keterangan:

a. Jika hasil skoring memiliki nilai diantara 4,67 - 6, maka aksesibilitas Stasiun Solo Balapan termasuk pada kategori sangat siap dalam melayani trayek kereta api penghubung Bandara Adi Soemarmo dengan Kota Surakarta

b. Jika hasil skoring memiliki nilai diantara 3,34-4,66, maka aksesibilitas Stasiun Solo Balapan termasuk pada kategori siap bersyarat. Artinya, pembangunan maupun operasional trayek kereta api penghubung Bandara Adi Soemarmo dengan Kota Surakarta, namun dengan syarat terdapat aspek - aspek yang perlu dioptimalkan atau diperbaiki, agar dapat benar - benar siap dalam pelayanan trayeknya.

c. Jika hasil skoring memiliki nilai diantara $2-3,33$, maka aksesibilitas Stasiun Solo Balapan termasuk pada kategori tidak siap. Artinya, masih banyak aspek aspek yang belum dapat memenuhi kriteria untuk melayani trayek kereta api bandara dan siap melayani kebutuhan masyarakat calon pengguna Kereta Api bandara Adi Soemarmo.

\section{HASIL DAN PEMBAHASAN}

Trayek kereta api penghubung Bandara Adi Soemarmo dengan Kota Surakarta direncanakan memiliki panjang jalur $12,5 \mathrm{~km}$, dengan memanfaatkan jalur eksisting rel kereta api Semarang - Surakarta sepanjang 3,5 km dan pembuatan jalur baru di samping jalur tol Trans Jawa ruas Solo - Kertosono sepanjang $10 \mathrm{~km}$. Pembangunan jalur baru ini membutuhkan lahan sekitar 129.421 m2 yang merupakan lahan milik PU Bina Marga, TNI AU, AP I, lahan warga yang berada di sekitar tol, dan lahan warga di Kelurahan Kadipiro, Nusukan, dan Gilingan. Meski lahan sekitar tol yang paling banyak dibutuhkan tapi lahan tersebut berupa sawah. Lahan KA Bandara yang melintasi pemukiman berada di Kelurahan Kadipiro, Nusukan, Gilingan, dan lahan TNI AU. Jalur rel kereta api akan dibangun ganda (double track) selebar $14 \mathrm{~m}$, sehingga banyak lahan warga yang berada di bantaran rel eksisting Semarang - Surakarta dan lahan warga yang ada di pinggir tol Trans Jawa yang akan digunakan untuk membangun jalur rel ini.

Trayek Kereta Api penghubung Bandara Adi Soemarmo dengan Kota Surakarta ini memiliki 3 stasiun transit, yaitu Stasiun Solo Balapan di Kota Surakarta, Stasiun Solo Balapan Baru, dan Stasiun Bandara Adi Soemarmo yang akan segara dibangun. Stasiun Solo Balapan Baru terletak di batas utara Kota Surakarta, di titik persimpangan antara rel eksisting dan rel baru yang akan dibangun di samping jalur tol Trans Jawa. Sementara Stasiun Bandara Adi Soemarmo akan dibangun di dalam kompleks Bandara Adi Soemarmo. 


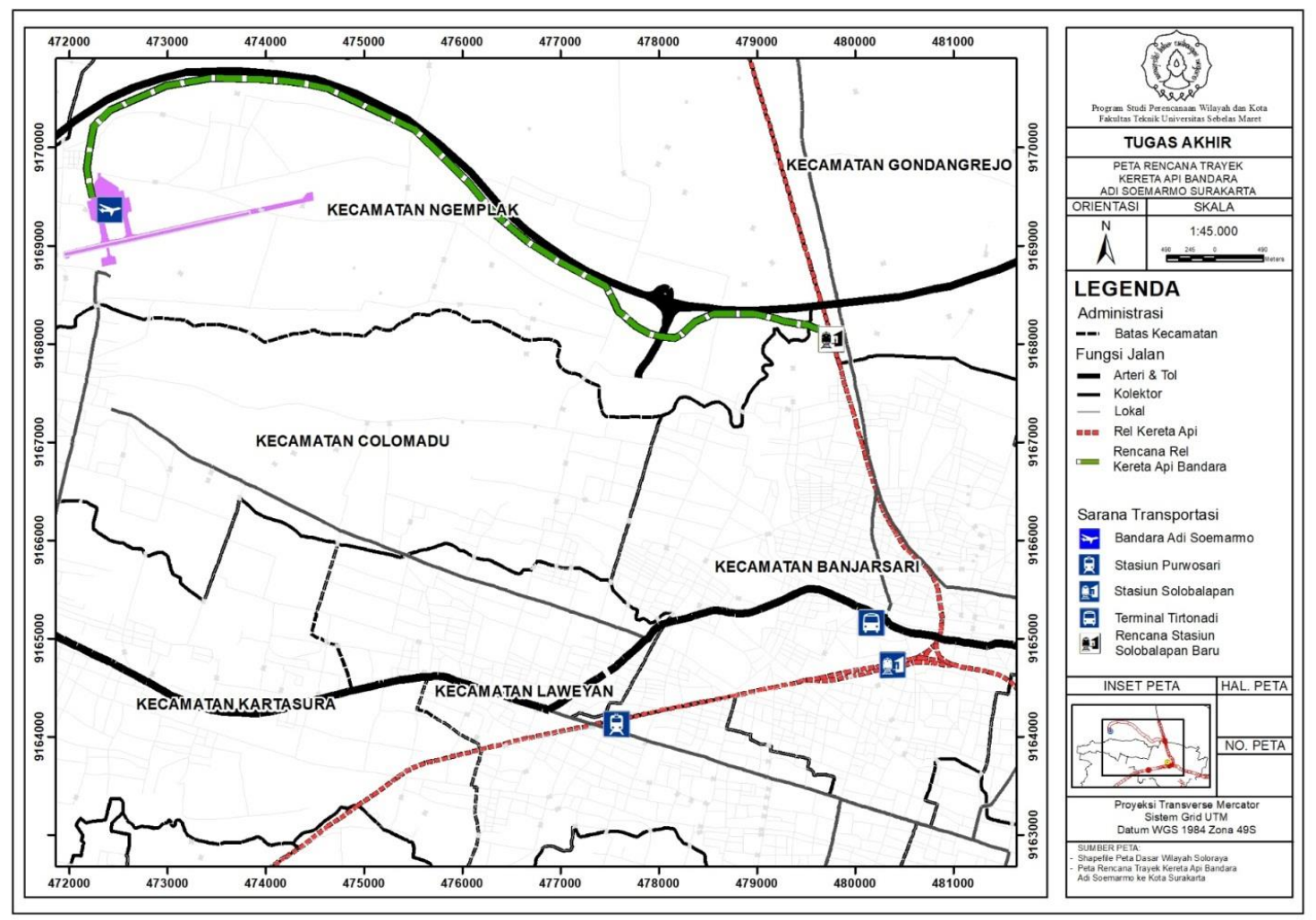

Gambar 1. Peta Rencana Trase Jalur Kereta Api Bandara Adi Soemarmo Sumber: Dokumentasi Peletakan Batu Pertama Pembangunan Trayek Kereta Api Bandara Adi Soemarmo, 2017. Diolah oleh Penulis

Pergerakan manusia memerlukan media (prasarana) tempat moda itu bergerak dan moda transportasi (sarana) (Tamin, 2000). Prasarana transportasi Kereta Api tentunya adalah jalan rel tempat kereta api bergerak, dan stasiun kereta api sebagai tempat pemberhentian dan pelayanan penumpang maupun barang (Miro, 2005). Seperti sarana kereta api di atas, prasarana kereta api juga sudah memiliki berbagai standar dan persyaratan yang dibuat oleh Kementerian Perhubungan Republik Indonesia. Sebagai contoh adalah Permenhub no. 11 Tahun 2012 tentang Tata Cara Penetapan Trase Jalur Kereta Api.

Sebagai prasarana yang akan melayani KA Bandara, terdapat cukup banyak teori dan usulan dari berbagai ahli dan lembaga tentang bagaimana aksesibilitas stasiun KA Bandara ini, contohnya dari JICA (2009) yang mengatakan bahwa stasiun harus terintegrasi dengan moda angkutan umum lainnya, stasiun bandara harus tersambung atau berjarak dekat dengan Terminal Bandara, dan Kouwenhoven (2008) yang mengatakan bahwa sebaiknya trayek KA Bandara tersambung langsung dengan kawasan pusat kota serta stasiun trayek sebaiknya memiliki jangkauan pelayanan yang luas. Lembaga ACRP (Airport Cooperative Research Program, 2008) mengatakan bahwa stasiun trayek KA Bandara juga sebaiknya tersambung atau menyediakan jaringan jalur pejalan kaki yang terkoneksi dengan 
Ghavi Yuda Sefaji dkk, Kesiapan Aksesibilitas Stasiun... pusat - pusat aktivitas atau tempat lainnya yang menjadi tujuan pengguna moda KA Bandara ini.

Dari hasil observasi lapangan, letak stasiun pelayanan trayek, yaitu stasiun Solo Balapan berjarak cukup jauh dari pusat kota, yaitu kawasan koridor jalan Slamet Riyadi, koridor jalan Jend. Soedirman, dan kompleks Kraton Kasunanan Surakarta serta koridor Pasar Klewer - jalan Dr. Radjiman. Untuk mencapai seluruh kawasan ini, masyarakat harus menggunakan moda transportasi pribadi, atau menggunakan moda Bus Kota Surakarta atau Bus Batik Solo Trans (BST). Stasiun Solo Balapan dilayani oleh rute Bus BST Koridor II dan Koridor VI. Selama ini, untuk mencapai Bandara Adi Soemarmo, masyarakat biasanya harus berganti rute dari Koridor II menuju rute Koridor I, yang mana hanya rute inilah yang bisa menjangkau kompleks Bandara Adi Soemarmo. Perpindahan rute koridor bus ini bisa dilakukan setelah bus BST sampai ke jalan Slamet Riyadi atau jalan Kol. Sutarto. Untuk berpindah ke rute Koridor lainnya, dapat dilakukan mulai dari jalan Kol. Sutarto, jalan Honggowongso, dan jalan Yosodipuro. Hal ini dinilai tidak sesuai dengan teori aksesibilitas nodal transportasi diatas, yang menyatakan bahwa nodal transportasi yang melayani moda KA Bandara harus memiliki aksesibilitas yang baik dengan kawasan pusat kota.

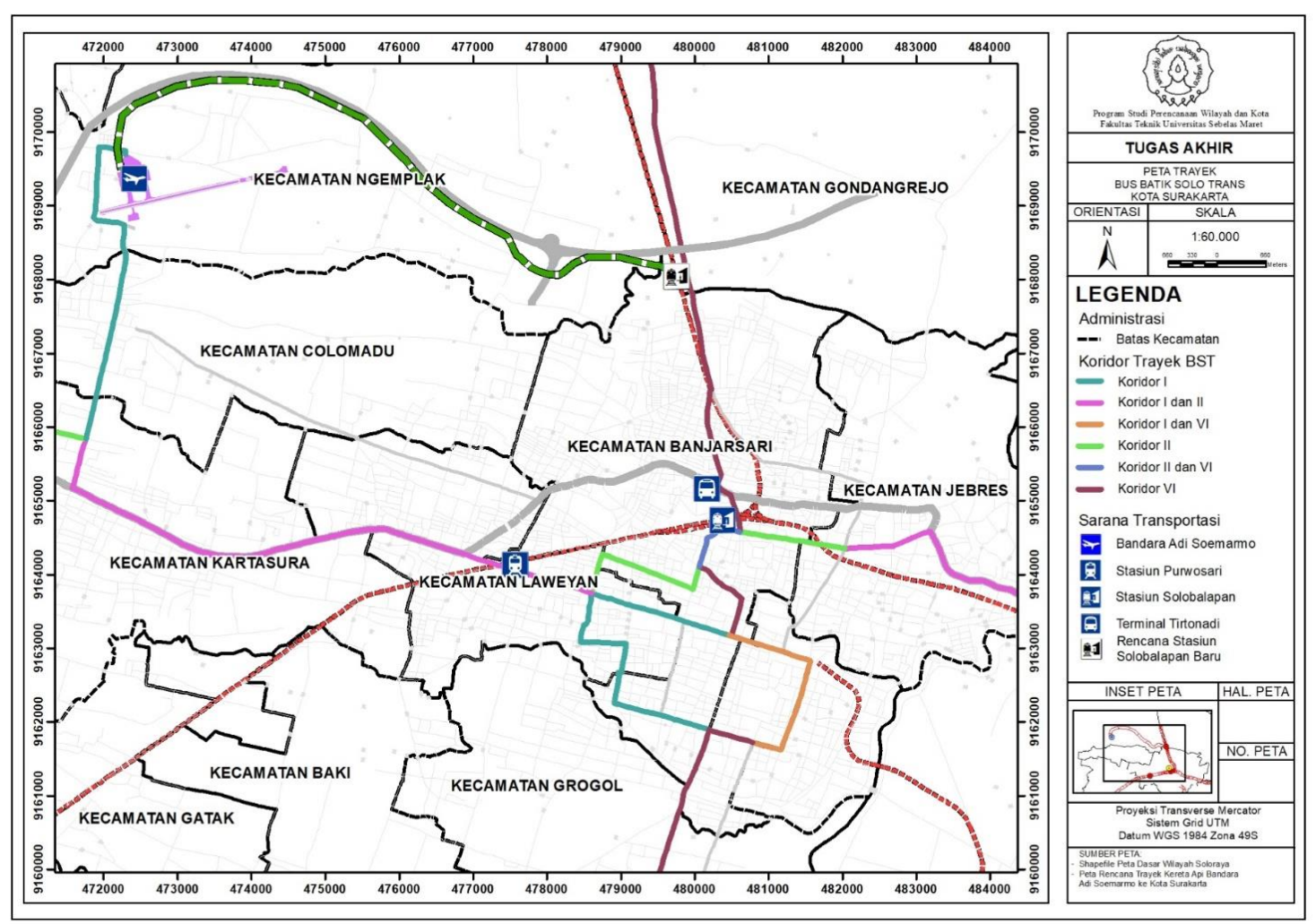

Gambar 4.2 Peta Rute Bis Batik Solo Trans Koridor I, II, dan VI Sumber: Dishubkominfo Kota Surakarta, 2017 


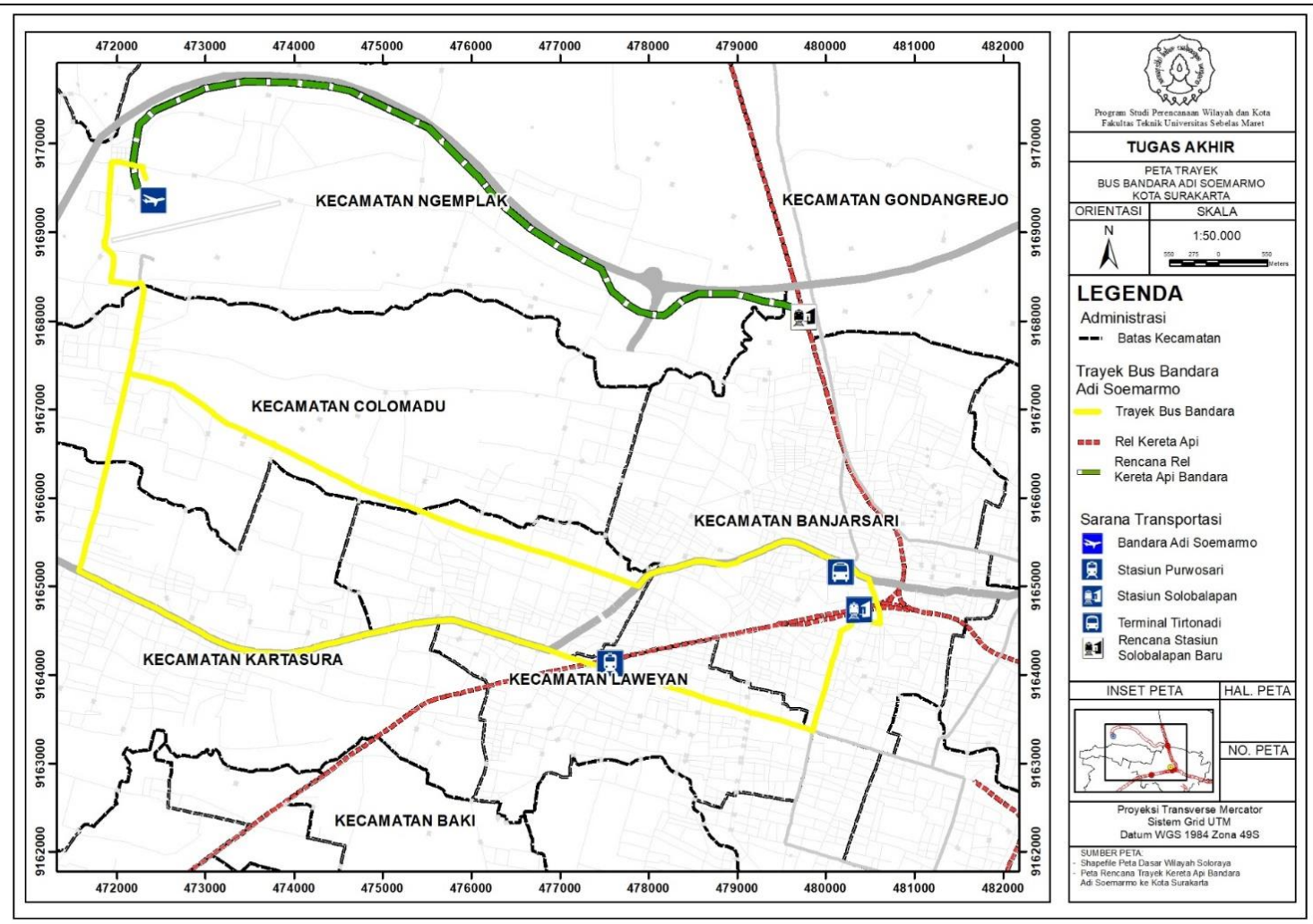

Gambar 3. Peta Rute Bus Bandara Adi Soemarmo

Sumber: Dishubkominfo Kota Surakarta, 2017

Kemudian dari tiga karakteristik aksesibilitas stasiun bandara dan stasiun kota, hanya dua karakteristik yang dipenuhi oleh dan Stasiun Solo Balapan, yaitu kapasitas parkir yang besar dan integrasi dengan moda transportasi umum kota, serta tidak memenuhi satu karakteristik yaitu terintegrasi dengan jaringan jalur pedestrian. Stasiun Solo Balapan memiliki kapasitas parkir yang luas, masing masing sesuai dengan standar ruang parkir yang ditetapkan oleh pengelolanya, yaitu Ditjen Perkeretaapian bersama PT. KAI. Stasiun Solo Balapan luas lahan parkirnya adalah $3.829 \mathrm{~m}^{2}$ dan dapat menampung 100 mobil dan 600 motor.

Untuk integrasi dengan moda transportasi umum lainnya, Stasiun Solo Balapan telah terlayani oleh trayek Bus BST Kota Surakarta Koridor I dan II, dan masyarakat dapat menaiki bus ini dari Stasiun Solo Balapan menuju Bandara dan sebaliknya dengan berpindah rute sekali saja. Stasiun Solo Balapan juga menyediakan moda transportasi pengumpan lainya, yaitu Taksi, Ojek, dan Becak. Tetapi, Stasiun Solo Balapan tidak memiliki integrasi dengan jaringan pedestrian, karena meskipun terletak di kawasan perdagangan jasa, pendidikan, dan permukiman Kota Surakarta, tidak terdapat jaringan pedestrian yang melaluinya.

Meskipun begitu, Stasiun Balapan Solo telah terintegrasi langsung dengan Terminal Tirtonadi Solo, via jembatan Skybridge kota Solo yang menjadi sarana pejalan kaki yang menghubungkan bangunan Stasiun Solo Balapan langsung 
Ghavi Yuda Sefaji dkk, Kesiapan Aksesibilitas Stasiun...

dengan Terminal Tirtonadi. Hal ini dinilai baik untuk integrasi antarmoda yang sering digunakan oleh masyarakat, dengan adanya kemudahan untuk mengakses baik stasiun Solo Balapan maupun Terminal Tirtonadi dengan berjalan kaki.

Tabel 2. Hasil Analisis Skoring

\begin{tabular}{|c|c|c|c|}
\hline \multicolumn{2}{|c|}{ Variabel Penelitian } & \multirow{2}{*}{ Penjelasan Hasil Analisis } & \multirow{2}{*}{$\begin{array}{c}\text { Slkor tiap } \\
\text { Variabel/Sub } \\
\text { Variabel } \\
\end{array}$} \\
\hline Variabel & Sub Variabel & & \\
\hline \multirow[b]{2}{*}{$\begin{array}{l}\text { Prasarana } \\
\text { Trayel } \\
\text { Kereta } \\
\text { Api } \\
\text { Bandara }\end{array}$} & $\begin{array}{l}\text { Aksesibilitas } \\
\text { trayek menuju } \\
\text { kawasan pusat } \\
\text { kota }\end{array}$ & $\begin{array}{l}\text { Letak stasiun pelayanan trayek, yaitu stasiun } \\
\text { Solo Balapan berjarak cukup jauh dari pusat } \\
\text { kota, dan harus menggunakan satu moda } \\
\text { tranportasi umum untuk mencapainya }\end{array}$ & 2 \\
\hline & $\begin{array}{l}\text { Aksesibilitas } \\
\text { stasiun kota } \\
\text { menuju } \\
\text { tempat lain via } \\
\text { berjalan } \\
\text { kaki/moda } \\
\text { transportasi } \\
\text { lainnya dan } \\
\text { sebaliknya }\end{array}$ & $\begin{array}{l}\text { Dari tiga karakteristik aksesibilitas stasiun } \\
\text { kota, hanya dua karakteristik yang dipenuhi } \\
\text { oleh Stasiun Solo Balapan, yaitu kapasitas } \\
\text { parkir yang memadai dan integrasi dengan } \\
\text { moda transportasi umum kota. Stasiun Solo } \\
\text { Balapan tidak memenuhi satu karakteristik } \\
\text { yaitu terintegrasi dengan jaringan jalur } \\
\text { pedestrian, namun memiliki akses langsung } \\
\text { menuju Terminal Tirtonadi melalui jalur } \\
\text { jembatan Skybridge Kota Surakarta }\end{array}$ & 2 \\
\hline \multicolumn{3}{|c|}{ TOTAL SKOR AKHIR } & 4 \\
\hline
\end{tabular}

Sumber: Peneliti, 2017

Dari kategori di atas, skor kesiapan (4) berdasarkan hasil analisis pada artikel ini berada pada kategori siap bersyarat atau dapat dikatakan Stasiun Solo Balapan memiliki kesiapan tingkat aksesibilitas yang berguna untuk pelayanan trayek Kereta Bandara yang tinggi, namun masih ada beberapa hal yang perlu diperbaiki untuk menambah tingkat pelayanan trayek dan stasiun Solo Balapan itu sendiri.

\section{KESIMPULAN}

Trayek KA Bandara Adi Soemarmo adalah trayek moda transportasi umum kereta api penghubung antara Bandara Adi Soemarmo Surakarta dengan Stasiun Solo Balapan Kota Surakarta. Pembangunan moda Kereta Api ini dilakukan untuk memberikan tambahan layanan moda transportasi umum antarmoda kepada masyarakat yang akan melakukan pergerakan menuju atau dari Bandara Adi Soemarmo, sekaligus mengurangi tingkat kepadatan lalu lintas yang dihasilkan dari pergerakan menuju atau dari Bandara Adi Soemarmo selama ini. Kereta Api ini direncanakan akan berhenti di Stasiun Solo Balapan. Karena kereta api Bandara ini nantinya akan menarik lebih banyak penumpang ke Stasiun Solo Balapan, maka perlu diteliti kesiapan tingkat aksesibilitas Stasiun Solo Balapan untuk mengakomodasi kinerja kereta Bandara pada nantinya. 
Stasiun Solo Balapan telah terintegrasi dengan Terminal Tirtonadi via jalur jembatan skybridge Kota Surakarta, dan juga telah terintegrasi dengan trayek Bus Batik Solo Trans yang melayani Kota Surakarta dan sekitarnya sebagai transportasi umum Kota. Meskipun begitu, Stasiun Solo Balapan juga belum memiliki tingkat aksesibilitas yang memenuhi indikator penelitian, yaitu mudah dijangkau dari kawasan pusat kota dan terintegrasi dengan jaringan pedestrian.

Berdasarkan aspek - aspek yang telah dijabarkan diatas, maka disimpulkan bahwa tingkat kesiapan aksesibilitas Stasiun Solo Balapan dalam melayani trayek Kereta Api Bandara ini berada pada kategori siap bersyarat. Sangat siap berarti Stasiun Solo Balapan dapat melayani Kereta Api Bandara Adi Soemarmo, namun tentu perlu perbaikan pada beberapa aspek, seperti fasilitas pendukung aksesibilitas untuk nodal transportasi yang melayani trayek KA Bandara, yaitu Stasiun Solo Balapan, yaitu seperti pengintegrasian stasiun dengan jaringan pedestrian kota Surakarta, penambahan area parkir, dan pengaturan area pembelian tiket dan check-in untuk penumpang kereta api Bandara.

\section{UCAPAN TERIMA KASIH}

Segala puji syukur penulis panjatkan kehadirat Allah SWT, dengan segala anugerah dan rahmatnya penulis dapat menyelesaikan penelitian ini. Tak lupa penulis mengucapkan terimakasih kepada pihak yang telah memberikan dukungan dalam penyusunan penelitian ini.

\section{REFERENCES}

BPS Kota Surakarta, 2017. Kota Surakarta Dalam Angka 2017

BPS Provinsi Jawa Tengah, 2016, Berita Resmi Statistik: Perkembangan Statistik Transportasi Jawa Tengah Bulan September 2016

Businessdictionary.com. "Readiness Definition". Diambil dari Businessdictionary.com.

http://www.businessdictionary.com/definition/readiness.html. Diakses 29 Oktober 2016

Coogan, Matthew A., bekerjasama dengan MarketSense Consulting LLC dan Jacobs Consultancy, 2008. Airport Cooperative Research Program (ACRP) Report 4: Ground Access to Major Airports by Public Transportation, Transportation Research Board, National Research Council, Washington, DC.

Direktorat Jenderal Perkeretaapian Kementerian Pehubungan Republik Indonesia, 2010, Rencana Induk Perkeretaapian Nasional tahun 2030. 2011.

Duncan, D.J. \& Hollander, S.C. 1977. Modern Retailing Management: Basic Concepts and Practices, Richard D. Irwin, Incorporated: University of Virginia, Virginia, Amerika Serikat

Eichinger, A. \& Knorr, A. 2004. Potential and Limitations of Air - rail Links - A General Overview, Materiealian des Wissenschaftsschwepunktes "Globalisierung der Welwirtschaft", Institute for World Economics and International Management (IWIM) 
Ghavi Yuda Sefaji dkk, Kesiapan Aksesibilitas Stasiun...

International Air-Rail Organisation (IARO). 2013. Submission to the Network Rail's Long Term Planning Process: Long Distance, Regional Urban and London and South East Market Studies

Japan International Cooperation Agency (JICA). 2009. Laporan Akhir Studi Pembangunan Sistem Kereta Api Regional Wilayah Jawa

Jou, R.C., Hensher, D.A \& Hsu, Tzu-Lan. 2011. Airport Ground Access Mode Choice After the Introduction of a New Mode: A Case Study of Taoyuan International Airport in Taiwan. Trasnportation Research Part E 47, 371 - 381

Kereta-api.info. 2016. "Proyek Stasiun Kereta Api Bandara Adi Soemarmo Solo Mulai Digarap Tahun 2017." Diambil dari Kereta-api.info, http://keretaapi.info/proyek-stasiun-kereta-api-bandara-adi-soemarmo-solo-mulaidigarap-tahun-2017-6436.htm. Diakses 15 Oktober 2016

Kouwenhoven, M. 2008. The Role of Accessibility in Passengers' Choice of Airports, Discussion Paper 2008-14, OECD/ITF

Miro, Fidel. 2005. Pengantar Perencanaan Transportasi: untuk Mahasisiwa, Perencana, dan Praktisi, Penerbit Erlangga, Jakarta.

Peraturan Daerah Kota Surakarta Nomor 1 Tahun 2012 tentang Rencana Tata Ruang Wilayah Kota Surakarta tahun 2011 - 2031. 2012.

Peraturan Daerah Kabupaten Boyolali Nomor 9 Tahun 2011 tentang Rencana Tata Ruang Wilayah Kabupaten Boyolali tahun 2011 - 2031. 2011.

Peraturan Menteri Perhubungan no. 11 Tahun 2012 tentang Tata Cara Penetapan Trase Jalur Kereta Api. 2012.

Peraturan Pemerintah Republik Indonesia No. 56 Tahun 2009 tentang Penyelenggaraan Pekeretaapian. .2009.

Peterson, Mark W. 2012. A New Procedure for Scoring Rail Transit Connections to U.S Airports, Tesis Sarjana Strata - 2 Faculty of Civil Engineering Virginia Poytechnic Institute and State University, Falls Church, Virginia, Amerika Serikat

Santoso. 2010. Model Konseling Keluarga Untuk Mengembangkan kesiapan Calon Tenaga Kerja Wanita (TKW) dan Keluarganya, Tesis Sarjana Strata - 3 Pasca Sarjana Bimbingan dan Konseling UPI, Bandung

Schank, J. 1999. Airport Access via Rail Transit: What Works and What Doesn't. Tesis Sarjana Strata - 2 Cambridge: Massachusetts Institute of Technology, Massachusetts, Amerika Serikat

Setiawati, F. A., Djemari Mardapi, \& Saifuddin Azwar. 2013. Penskalaan Teori Klasik Instrumen Multiple Intelligences Tipe Thurstone dan Likert. Jurnal Penelitian dan Evaluasi Pendidikan, Tahun 17, No.2, 2013

Tamin, Ofyar Z. 2000. Perencanaan dan Pemodelan Transportasi, Penerbit ITB, Bandung.

Undang - Undang Republik Indonesia No. 23 Tahun 2007 tentang Perkeretaapian. 2007. 